\title{
Chemical Characteristics of Precipitation during Winter Season over Delhi: Source Identification of Measured Species
}

\author{
Sanjay Tyagi ${ }^{1}$, Suresh Tiwari ${ }^{2}$, Anuradha Mishra ${ }^{1}$, Abhijit Chatterjee ${ }^{3}$ and \\ Deewan Singh Bisht ${ }^{2}$
}

${ }^{1}$ Department of Environmental Science, School of Vocational Studies and Applied Sciences, Gautam Buddha University, Greater NOIDA, UP, 201312, India

${ }^{2}$ Indian Institute of Tropical Meteorology, Pune; New Delhi Branch, 110060, India

${ }^{3}$ National Facility on Astroparticle Physics and Space Science, Bose Institute, 16, AJC Bose

Road, Darjeeling 734101, West Bengal, India

Email: styagi6@gmail.com

\begin{abstract}
The study of precipitation chemistry in the winter season over the northern part of India is vital as the atmosphere is highly loaded with atmospheric aerosols due to emissions and meteorological conditions. Precipitation samples were collected in Delhi and analyzed for major cations $\left(\mathrm{Na}^{+}, \mathrm{NH}_{4}{ }^{+}, \mathrm{K}^{+}, \mathrm{Ca}^{2+}\right.$, and $\left.\mathrm{Mg}^{2+}\right)$ and anions $\left(\mathrm{F}^{-}, \mathrm{Cl}^{-}, \mathrm{NO}_{3}{ }^{-}, \mathrm{SO}_{4}{ }^{2-}\right.$ and $\left.\mathrm{HCO}_{3}{ }^{-}\right)$along with $\mathrm{pH}$ and conductivity. The volume weighted mean $\mathrm{pH}$ of rainwater $(\mathrm{RW})$ was $5.76 \pm 0.61$, with $\sim 42 \%$ samples being acidic (mean $\mathrm{pH}=5.20$ of acidic rain). Specific conductivity was $\sim 16 \%(84.93$ $\mu \mathrm{S} / \mathrm{cm}$ ) lower specific conductivity for the acid RW samples as compared to the non-acidic RW samples $(101.20 \mu \mathrm{S} / \mathrm{cm})$. The sum of ionic constituents was $1273.41 \pm 749.91 \mu \mathrm{eq} / 1$, with anion's sum contribution being $17 \%$ lower than the sum of cations. Neutralization factors of major cations were in the order of $\mathrm{Ca}^{2+}(0.83)>\mathrm{NH}_{4}{ }^{+}(0.36)>\mathrm{Mg}^{2+}(0.11)$ over Delhi. Second higher (cation) contribution of $\mathrm{NH}_{4}{ }^{+}$in $\mathrm{RW}$ over Delhi may be attributed to the ever increasing vehicular density and the initiation of catalytic converters in public transport. Different source apportionment methods, including principal component analysis (PCA), enrichment factor (EF), and backtrajectory $(72 \mathrm{~h})$ analysis were used for estimating the sources of RW. Trajectory analysis indicated three different air masses over Delhi of easterly, westerly and southerly/southeasterly wind regime. The PCA analysis shows three major factors for measured ions and was assigned to mixed source influenced by crustal, anthropogenic and marine origins, whereas, $\mathrm{NH}_{4}{ }^{+}$and $\mathrm{HCO}_{3}{ }^{-}$ to the local biomass burning and soil dust respectively.
\end{abstract}

Keywords: Chemical characteristics; Acid rain; Back trajectory, Principle component analysis

\section{Introduction}

Global concern about climate change and atmospheric chemistry over the past decades has led to additional investigations on atmospheric aerosols (Menon et al., 2002; Aneja et al., 2006). Ever increasing the quantity of atmospheric aerosols as a function of human and anthropogenic activities, consequently, impart an increasing impact on climate change (IPCC, 2001, 2007). A dynamic association existing between atmospheric aerosols' 
sources, transportation trajectories, and their deposition sites vary according to different pollutants in the atmosphere (Kuniyal et al., 2015). Chemical constituency of atmospheric aerosols can be reviewed by evaluating their acidic and alkaline nature (Safai et al., 2010). Investigation of precipitation is one of the appropriate methodologies to access the chemical composition of atmospheric pollutants (Tiwari et al., 2016). High frequency of aerosol fog/haze is prevalent over the North India including Delhi during the winter months (December to February) (Ganguly et al., 2006). It gets abridged due to intermittent precipitation under the influence of Western Disturbances (WD), non-monsoonal precipitation systems in the westerly's (Ali et al., 2004). The areal extension of the winter precipitation increases over the north India when such WD's interacts with southwesterly winds from the Arabian Sea and easterly/southeasterly from the Bay of Bengal (Chand and Singh, 2015).

Rainfall during the prolonged winter fog is a vital process for scavenging atmospheric pollutants (Tiwari et al., 2016). Fog forms in the lower layer of the troposphere where aerosols and gases are most abundant. Rain drops are quite large, almost 100 times higher than fog droplets (Lange et al., 2003; Ali et al., 2004), hence, the concentrations of RW is a considerable determinant of the atmospheric chemical composition during the pre-existing fog aerosols. Atmospheric particles and gases affect the chemistry of rainwater (RW: precipitation) and reveal the air quality of the area where rain occurs (Al-Khashman, 2009). Rainfall is affected by local and transported particles from the vicinity (Chate et al., 2011; Akpo et al., 2015; Tiwari et al., 2016). The dissolved ions in the rainwater give details on both local and long-range transported atmospheric pollutants and alteration in the rainfall's effect on ecosystems through wet deposition (Li et al., 2007). A combination of local and regional pollutants, cloud formation processes, and precipitation amounts affects the chemical composition of RW (Zhao et al., 2008; Calvo et al., 2010). Quantitative measurement of wet deposition compositions determines the relative contributions of the various natural and anthropogenic sources. The scavenging of atmospheric pollutants affects the chemical composition and the $\mathrm{pH}$ of rainwater. The acidic rain is primarily caused by incorporation of anthropogenic pollutants such as oxides of sulfur and nitrogen and other acid precursors (Migliavacca et al., 2005; Bisht et al., 2015), whereas, neutralization of acidity in RW can be due to airborne dust and ammonia released from natural and man-made sources (Al-Momani et al., 1995). The amount of the air pollutant reduction by precipitation scavenging effect can be affected by the amount, duration, and intensity of rainfall. Real rainfall events have several characteristics such as rainfall volume, duration, average intensity, inter-event time (IET), peak intensity, and a number of peaks.

Different climatic conditions influence trace substance concentrations in the RW and gases like $\mathrm{SO}_{2}$ and $\mathrm{NO}_{2}$ are converted into acidic forms after getting dissolved in cloud water (Baron and Denning, 1993). Due to the influence of natural and anthropogenic particles, the chemistry of RW varies from synoptic scale to mesoscale (Kulshrestha et al., 2005; Tiwari et al., 2016); thereby providing the input of anthropogenic as well as natural components of various ecosystems. In recent years, studies on precipitation chemistry over Indian region have been conducted especially during the south-west summer monsoon season (Safai et al., 2010; Das et al., 2011; Salve et al., 2011; Tiwari et al., 2012; Budhavant et al., 2014; Bisht et al., 2015; Tiwari et al., 2016; references therein), however, there is a lack of information on the winter RW chemistry over the northern part of India leaving crucial gaps in the scientific understanding of atmospheric pollutants. Therefore, there is always a larger need to generate new and better quality data on RW chemistry over these Indian regions. Over national capital 
Open access e-Journal

Earth Science India, eISSN: $0974-8350$

Vol. 9 (IV), October, 2016, pp. 150 - 166

http://www.earthscienceindia.info/

region of Delhi, around 13-15 days of rainfall is experienced during the winter season. The present work is envisaged to bridge this knowledge gap of RW chemistry during the winter season over Delhi by estimating the atmospheric deposition and evaluating the characteristics of species over the study region of north India. The second and third objectives are to identify possible sources of the various constituents of RW and comparison of the results with the past studies across India and abroad respectively.

\section{Experimental Setup}

\section{Site Description}

Rainwater samples collected during the winter season $\left(1^{\text {st }}\right.$ December 2014 to $28^{\text {th }}$ February 2015) in the premises of Indian Institute of Tropical Meteorology (IITM), New Delhi branch $\left(28.62^{\circ} \mathrm{N} 77.17^{\circ} \mathrm{E}\right)$, lying in central Delhi. The site is surrounded by a green belt (three sides) and residential colony (one side). The meteorological data of three different meteorological observatories (MO's) spread across National Capital Region (NCR) of Delhi was simultaneously analyzed during the study period. These MO's are located at Indira Gandhi International Palam Airport (PLM) $\left(28.55^{\circ} \mathrm{N} 77.09^{\circ} \mathrm{E}\right)$, Hindon Airport (HND) $\left(28.43^{\circ} \mathrm{N}, 77.22^{\circ} \mathrm{E}\right)$ and Safdarjung Airport (SFD) $\left(28.35^{\circ} \mathrm{N}, 77.12^{\circ} \mathrm{E}\right)$. Delhi is characterized by topographical areas like the extension of the Aravalli ridge, forests, the rivers Ganga, Yamuna, and Hindon, fertile cultivated land, and is a dynamic rural-urban region with a total population of approximately 46 million (Tyagi et al., 2016). The Delhi in northern India is influenced by four major seasons; winter (December to February), SW summer monsoon (July to September.), pre-monsoon (March to June and post-monsoon (October to November) (IMD, 2016). Winter season is the coldest period of the year characterized by low temperatures, poor visibility conditions, and low boundary layer heights. During such conditions, pollutants do not disperse or mix with free troposphere (Tiwari et al., 2008). The impact of such conditions is discernible as poor visibility and high levels of pollutants over Delhi and adjoining region. During the winter season, on an average (monthly) 4 to 6 Western Disturbances (WD's) move across north India and break the spell of the high frequency of widespread fog by causing clouding and precipitation over the region (Kumar and Yadav, 2015).

\section{Sampling Collection Procedure}

A total of seven RW samples were collected during the study period by rain collectors at about $15 \mathrm{~m}$ above the ground level, on the rooftop of a building of the Institute situated in the thoroughly urbanized central part of Delhi. The sampling area is primarily a residential area, and no large pollutant source exists nearby which could have influenced the sampling site directly (Fig.1). The RW samples were taken on an event-to-event basis. Rain collector consists of a polypropylene funnel $(20 \mathrm{~cm}$ in diameter) with a 2-1 polypropylene bottle (Tiwari et al., 2012). The rain collector was washed with triple distilled water twice daily in the morning and evening and also prior to installation of the new bottle and after the collection of each sample for prevention of any type of contaminations. Immediately after collection, a small portion of collected samples was used for $\mathrm{pH}$ and electrical conductivity measurements and those samples were drained after the measurement. The $\mathrm{pH}$ was measured 
soon after the collection using a digital $\mathrm{pH}$ meter (Sartorious Professional Meter, PP20) which was standardized by standard solutions of $\mathrm{pH}$ of 4.0 and 9.2. Thymol (200 mg L-1) was added to the samples as a preservative to prevent the decomposition of volatile components and ammonium (Gillett and Ayers, 1991). The samples were then stored in a refrigerator at $4^{\circ} \mathrm{C}$ until chemical analysis.

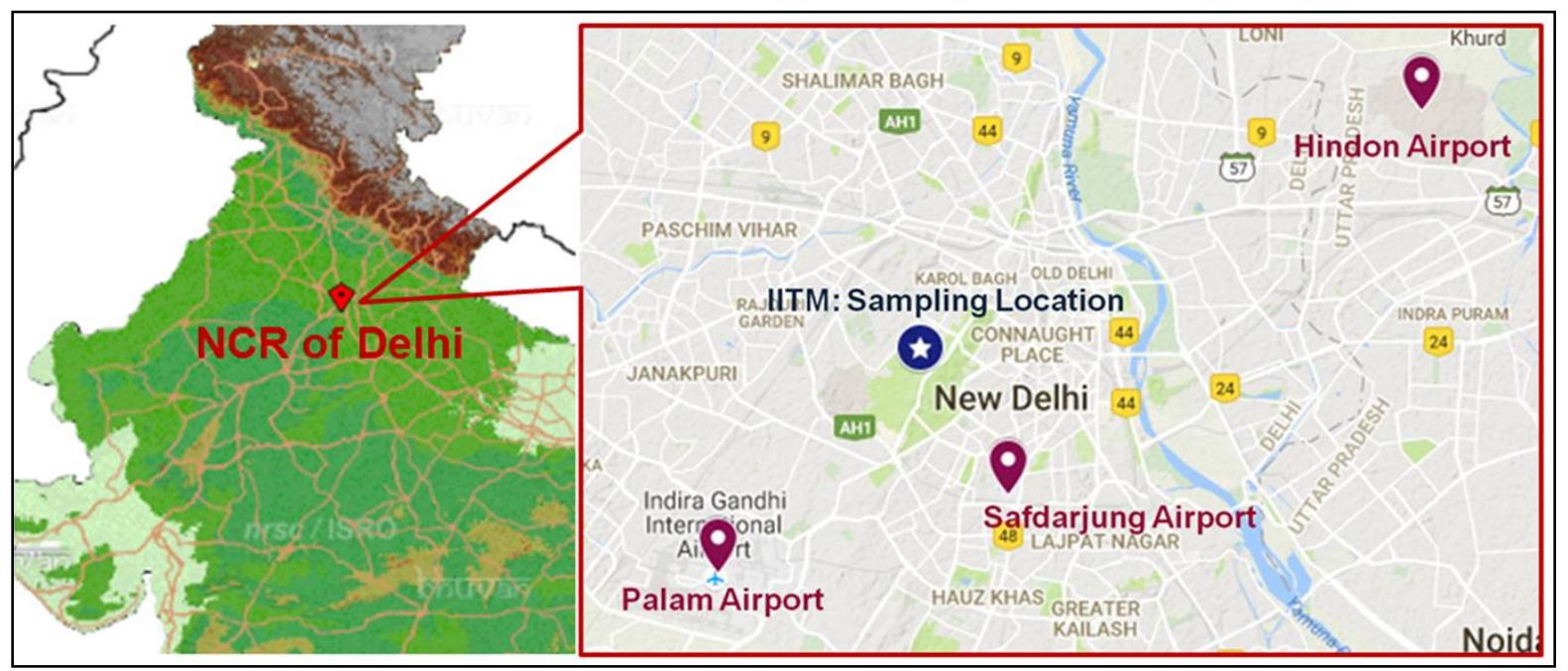

Fig. 1: Map of National Capital Region (NCR) of Delhi depicting sampling location at Indian Institute of Tropical Meteorology (IITM) and meteorological observatories: Indira Gandhi International Palam Airport (PLM), Hindon Airport (HND) and Safdarjung Airport (SFD).

\section{Chemical Analysis and Quality Control}

The RW samples were filtered using $0.45 \mu \mathrm{m}$ Millipore filter paper and transferred to $100 \mathrm{ml}$ polypropylene bottles pre-cleaned in Milli-Q water. The major chemical species such as anions $\left(\mathrm{F}^{-}, \mathrm{Cl}^{-}, \mathrm{NO}_{3}^{-}\right.$and $\left.\mathrm{SO}_{4}{ }^{2-}\right)$ and cations $\left(\mathrm{Na}^{+}, \mathrm{NH}_{4}^{+}, \mathrm{K}^{+}, \mathrm{Ca}^{2+}\right.$ and $\left.\mathrm{Mg}^{2+}\right)$ were quantitatively determined by Ion Chromatograph (DIONEX-2000, USA). The analytical column IonPac-AS15 with micro-membrane suppressor ASR Sultra II $2 \mathrm{~mm}, 38 \mathrm{mM}$ Potassium Hydroxide and the IonPac-CS17 column with micro-membrane suppressor CSRS ultra II $2 \mathrm{~mm}, 6 \mathrm{mM}$ methyl sulfonic acid as eluents and triple distilled water as regenerator were used for anion and cations, respectively. The details of the chemical analysis procedure are discussed elsewhere (Tiwari et al., 2012; Bisht et al., 2015). The data quality was assessed by ionic balance, which is an indicator of the completeness of measured parameters. The ionic ratio between the sum of anions and sum of cations in the present study was 0.83 , that is, less than unity, it is due to organics. A significant correlation $(r=0.82)$ at $99 \%$ confidence level was found in between sum of anions and cations (Fig.2), which are within the range of quantitative ionic balance (Sanusi et al., 1996). It indicated the nearby completeness of the analyzed ions. Several field blank samples were also analyzed for the correction of the sample data. The detection limits for $\mathrm{Na}^{+}, \mathrm{NH}_{4}^{+}, \mathrm{K}^{+}, \mathrm{Ca}^{2+}, \mathrm{Mg}^{2+}, \mathrm{Cl}^{-}, \mathrm{NO}_{3}{ }^{-}$ and $\mathrm{SO}_{4}{ }^{2-}$ are $0.05,0.06,0.08,0.1,0.05,0.06,0.08$ and 0.07 ppm respectively. 


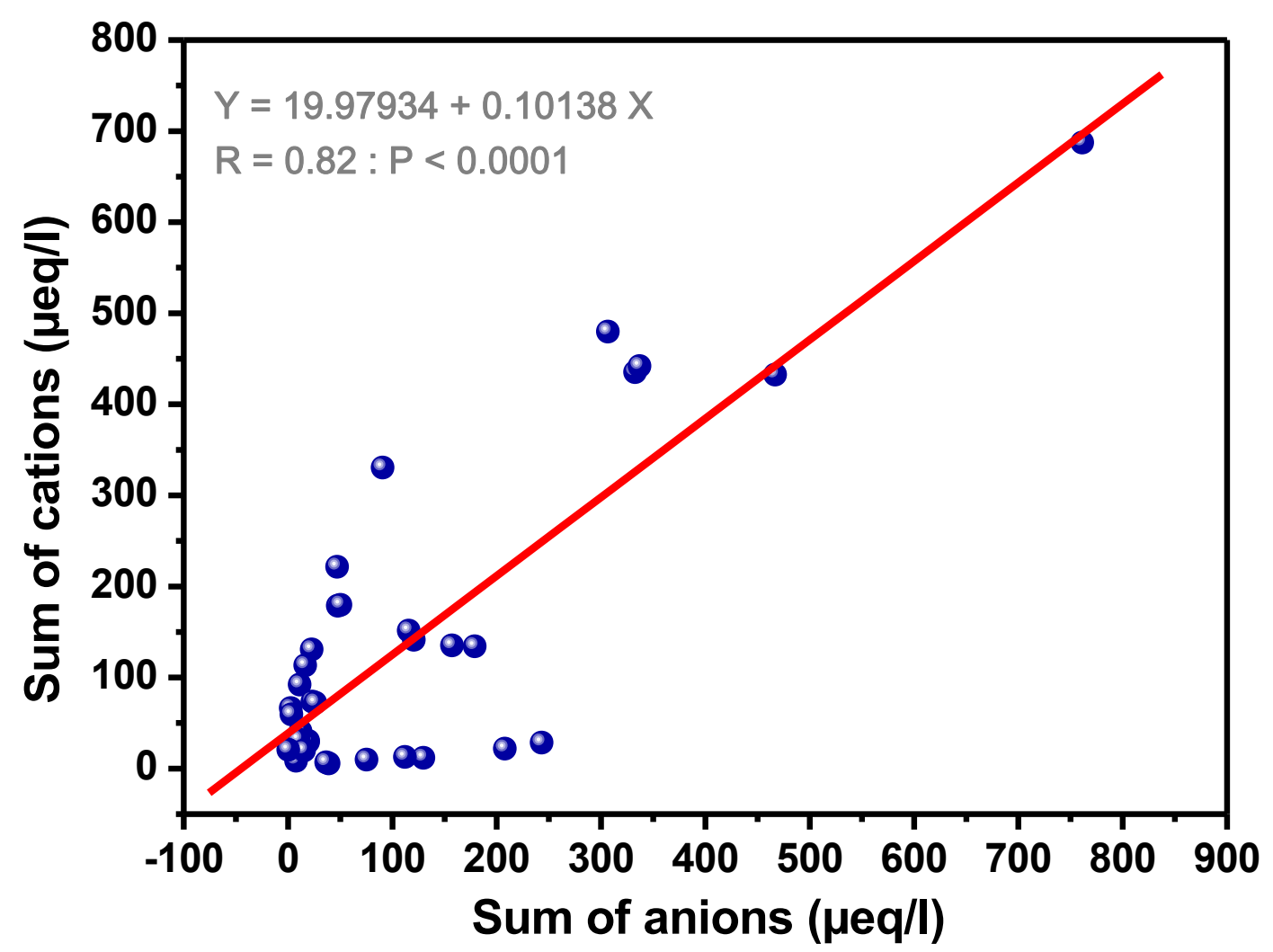

Fig. 2: Regression analysis between sums of anions and sums of cations of winter rainwater.

\section{Results and Discussion}

\section{Meteorological Parameters Associated with Rain Occurrences during the Winter Season}

Information on meteorological elements namely, dry bulb temperatures, relative humidity (RH), the frequency of fog occurrences and the number of RW samples collected at Delhi during the winter season, $2014-2015$ are presented in Table-1. The monthly occurrence of fog over SFD/PLM/HND MO's in Dec was 21/19/22 days whereas in Jan \& Feb was $30 / 30 / 30$ and $16 / 20 / 16$ respectively. The monthly average temperatures $\left({ }^{\circ} \mathrm{C}\right)$ over SFD MO in $\mathrm{Dec} / \mathrm{Jan} /$ Feb were $15.5 \pm 4.6 / 12.8 \pm 1.6 / 19.1 \pm 2.6$ respectively whereas PLM MO recorded $13.4 \pm 5.8 / 11.9 \pm 3.3 / 19.0 \pm 5.2 \mathrm{in} \mathrm{Dec/Jan/Feb} \mathrm{respectively} \mathrm{and} \mathrm{HND} \mathrm{MO} \mathrm{recorded} 12.7$ $\pm 5.9 / 11.6 \pm 3.4 / 17.6 \pm 5.3 \mathrm{in} \mathrm{Dec/Jan/Feb} \mathrm{respectively.} \mathrm{The} \mathrm{monthly} \mathrm{average} \mathrm{RH} \mathrm{( \% )} \mathrm{over}$ SFD MO in Dec/Jan/Feb was $69 \pm 13 / 78 \pm 09 / 65 \pm 10$ respectively whereas PLM MO recorded $74 \pm 25 / 87 \pm 15 / 64 \pm 22$ in Dec/Jan/Feb respectively and HND MO recorded 76 $\pm 25 / 91 \pm 15 / 75 \pm 22 \mathrm{in} \mathrm{Dec/Jan/Feb} \mathrm{respectively.} \mathrm{The} \mathrm{seasonal} \mathrm{rain} \mathrm{occurrence} \mathrm{in} \mathrm{winter}$ season $2014-15$ is $\approx 13$; monthly occurrence being $2 / 9 / 2$ in Dec/Jan/Feb respectively but only 07 RW samples, (1/5/1 in Dec/Jan/Feb respectively) were selected for analysis. This is because the other samples were discarded either due to their being contaminated in some way or due to their not being enough in the amount needed for a complete chemical analysis. 
Table-1: Fog, precipitation and other meteorology parameters during winter 2014-15 of Delhi.

\begin{tabular}{|c|c|c|c|c|c|c|c|c|c|}
\hline \multirow[b]{3}{*}{ Month } & \multirow[b]{3}{*}{ MO } & \multirow{3}{*}{$\begin{array}{c}\begin{array}{c}\text { Fog } \\
\text { frequency }\end{array} \\
\text { ( days) } \\
\end{array}$} & \multirow{3}{*}{$\begin{array}{c}\begin{array}{c}\text { Rainfall } \\
\text { Frequency }\end{array} \\
\text { (days) } \\
\end{array}$} & \multirow{3}{*}{$\begin{array}{c}\text { Rainfall } \\
(\mathrm{mm})\end{array}$} & \multirow{3}{*}{$\begin{array}{c}\text { Rain } \\
\text { Samples } \\
\text { Quantity }\end{array}$} & \multicolumn{4}{|c|}{ Met Elements } \\
\hline & & & & & & \multicolumn{2}{|c|}{ Temp $\left({ }^{\circ} \mathrm{C}\right)$} & \multicolumn{2}{|c|}{ RH (\%) } \\
\hline & & & & & & Mean & SD & Mean & SD \\
\hline \multirow{3}{*}{$\begin{array}{c}\text { Dec } \\
2014\end{array}$} & SFD & 21 & 2 & 13.4 & \multirow[t]{3}{*}{ 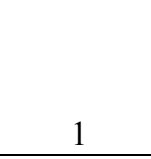 } & 15.5 & 4.6 & 69 & 13 \\
\hline & PLM & 19 & 2 & 17.4 & & 13.4 & 5.8 & 74 & 25 \\
\hline & HND & 22 & 2 & 6.3 & & 12.7 & 5.9 & 76 & 25 \\
\hline \multirow{3}{*}{$\begin{array}{c}\text { Jan } \\
2015\end{array}$} & SFD & 30 & 9 & 23.9 & \multirow[b]{3}{*}{5} & 12.8 & 1.6 & 78 & 9 \\
\hline & PLM & 30 & 9 & 26.7 & & 11.9 & 3.3 & 87 & 15 \\
\hline & HND & 30 & 9 & 24.2 & & 11.6 & 3.4 & 91 & 15 \\
\hline \multirow{3}{*}{$\begin{array}{c}\text { Feb } \\
2015\end{array}$} & SFD & 16 & 4 & 2 & \multirow[b]{3}{*}{1} & 19.1 & 2.6 & 65 & 10 \\
\hline & PLM & 20 & 2 & 5.8 & & 19.0 & 5.2 & 64 & 22 \\
\hline & HND & 16 & 2 & 0.7 & & 17.6 & 5.3 & 75 & 22 \\
\hline
\end{tabular}

\section{Variability of pH and Specific Conductivity}

The definition of acidic precipitation is a $\mathrm{pH}$ less than 5.65. This is the $\mathrm{pH}$ associated with the weak solution of carbonic acid $\left(\mathrm{H}_{2} \mathrm{CO}_{3}\right)$ that forms when water droplets in clouds are in chemical equilibrium with $\mathrm{CO}_{2}$. The increased $\mathrm{CO}_{2}$ concentration in the atmosphere $(\sim 400$ $\mathrm{ppm}$ ) is through the burning of fossil fuels like coal, oil, natural gas etc. (Charlson and Rodhe, 1982). The volume-weighted mean (VWM) of $\mathrm{pH}$ value during the present study over Delhi was $5.76 \pm 0.61$ varying from 4.49 to 6.27 (Fig. 3) indicating the generally non-acidic nature of the RW over Delhi. However, in few cases, the VWM pH values were found to be lower than the threshold value for acidic RW. During the study period, $\sim 42 \%$ of the RW samples were acidic (mean $\mathrm{pH}=5.20$ ) and rest of the samples were more basic than "acid rain." Very high concentrations of $\mathrm{SO}_{4}{ }^{2-}$ and $\mathrm{NO}_{3}{ }^{-}$might be responsible for acidic $\mathrm{pH}$, especially in case of sample V. The episode of acid rain in the winter season indicates that emission of oxides of nitrate and sulphate, precursor gases for acid formation in atmosphere, continues to be high in Delhi despite tough initiatives of Indian government to alleviate pollution by launching of compressed natural gas $(\mathrm{CNG})$ as the primary fuel for public transport in the city and relocation of polluting industries outside New Delhi. Also, organic acids could be boosting acidity in RW over Delhi. The organic acids, in particular, formic and acetic acids play a significant role in precipitation acidity in urban areas (Pen a et al., 2002). Tiwari et al. (2007) reported alkaline nature of RW having an average $\mathrm{pH}$ (6.39) at eight different locations around National Capital Region of Delhi ranging from 5.77 to 6.62. The measured specific conductively during the study period was $94.22 \mu \mathrm{S} / \mathrm{cm}$ and varied from 40.33 to $191.90 \mu \mathrm{S} / \mathrm{cm}$. The specific conductively was found to be having $\sim 16 \%(84.93$ $\mu \mathrm{S} / \mathrm{cm}$ ) lower specific conductivity for the acidic RW samples as compared to the non-acidic RW samples $(101.20 \mu \mathrm{S} / \mathrm{cm})$. Thus, higher concentrations of alkaline species produced such more basic samples (Piñeiro et al., 2014; Tiwari et al., 2016). 


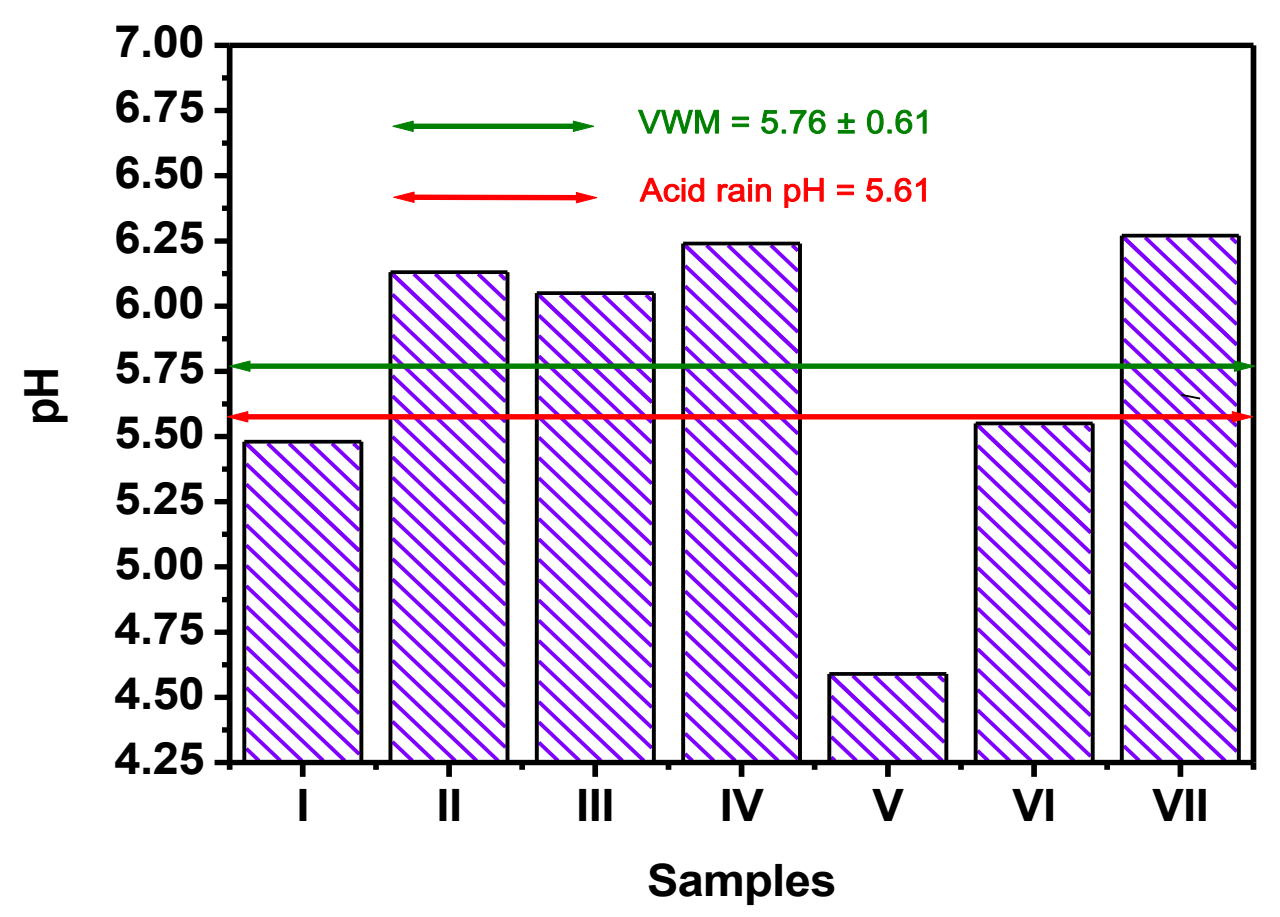

Fig. 3: Mean $\mathrm{pH}$ variation of winter rainwater samples at Delhi. Note Green line indicates the mean $\mathrm{pH}$ and Red line indicates the neutral cloud water $\mathrm{pH}$. Samples I (December, 2014), II to VI (January, 2015) and VII (February, 2015).

\section{Ionic Composition of Rainwater}

A function of the proportion of acidic and alkaline constituents in the RW sample defines the chemistry of rainwater. The volume weighted means (VWM) of measured chemical components were calculated according to the formula proposed by Galloway et al. (1984) and summarized in Table-2. During the study period, it was found that the sum of volume weighted means $(\mathrm{VWM})$ of ionic constituents over Delhi was $1273.41 \pm 749.91 \mu \mathrm{eq} / 1$ which is lower than the value $(1924 \pm 1633.6 \mu \mathrm{eq} / \mathrm{l})$ reported in New Delhi during the winter season (December - February) (Kumar et al., 2014). A Large value of standard deviation is due to the small resolution of the data and large sample-to-sample variability. The contribution of anions in the sum of measured ion was $17 \%$ lower than the measured sum of cations. The dominant ions in RW were calcium $\left(\mathrm{Ca}^{2+}\right)$, sulfate $\left(\mathrm{SO}_{4}{ }^{2-}\right)$ and ammonium $\left(\mathrm{NH}_{4}{ }^{+}\right)$, and their weighted mean concentrations were 394.72 $\pm 193.52,353.88 \pm 214.91$ and $172.91 \pm 83.32 \mu \mathrm{eq} / \mathrm{l}$, respectively. The very high concentrations of $\mathrm{Ca}^{2+}$, and $\mathrm{SO}_{4}{ }^{2-}$ could be due to pollution sources, transport of pollutants and windblown dust whereas higher concentrations of $\mathrm{NH}_{4}{ }^{+}$may be attributed to increased humidity levels favoring partitioning into the aerosol phase (Singh and Kulshrestha, 2012). Delhi is considered among the most polluted megacities of the world and the air quality report published by the Central Pollution Control Board (CPCB), Government of India (GoI) reported that Delhi has exceeded the annual average respirable particulate matter (RSPM) concentration limit by more than four times the national annual standards (Maji et al., 2015). The ionic concentrations ( $\mu \mathrm{eq} / \mathrm{l}$ ) followed the sequence of $\mathrm{Ca}^{2+}>\mathrm{SO}_{4}{ }^{2-}>\mathrm{NH}_{4}{ }^{+}>\mathrm{NO}_{3}{ }^{-}>\mathrm{Cl}^{-}>\mathrm{Na}^{+}>\mathrm{Mg}^{2+}>\mathrm{F}^{-}>\mathrm{K}^{+}>\mathrm{HCO}_{3}{ }^{-}$ 
whereas the category-wise abundance was in the order of $\mathrm{Ca}^{2+}>\mathrm{NH}_{4}{ }^{+}>\mathrm{Na}^{+}>\mathrm{Mg}^{2+}>\mathrm{K}^{+}$for cations and $\mathrm{SO}_{4}{ }^{2-}>\mathrm{NO}_{3}{ }^{-}>\mathrm{Cl}^{-}>\mathrm{F}^{-}>\mathrm{HCO}_{3}{ }^{-}$for the anions. The percentage contribution of individual cations and anions in RW were calculated and depicted in Fig. 4. It may be noted that among the cations, $\mathrm{Ca}^{2+}$ alone contributed to about $57 \%$ of the total cationic strength of wet precipitation, whereas, among the anions, $\mathrm{SO}_{4}{ }^{2-}$ made up about $64 \%$ of total anionic strength. The overall contributions of cations and anions to the ionic strength were $55 \%$ and $45 \%$, respectively, indicating nearly equal distribution. Kumar et al. (2014) recorded average cations as $52 \%$ and an average anion as $48 \%$ in RW over Delhi during January 2010 March 2011. Most of the available research work is based on the data sets for annual average (monsoon season); information on the winter season for comparison was not available. Precipitation analysis over Delhi's environment reflects high-soluble ion load compared with other studies. Precipitation of Delhi are enriched in soluble $\mathrm{Ca}^{2+}$ and $\mathrm{NH}_{4}{ }^{+}$ions compared with that from other places, and these cations are responsible for alkaline nature of RW, whereas, there have been cases of acid rain in China due to high nitrate and sulfate (Wang and Han, 2011; Kumar et al., 2014). These studies indicate that RW chemistry is subjective and depends on geographical region and confined local pollution sources. The mean values of $\mathrm{SO}_{4}{ }^{2-}(353.88 \mu \mathrm{eq} / \mathrm{l})$ and of $\mathrm{NO}_{3}{ }^{-}(120 \mu \mathrm{eq} / \mathrm{l})$ were approximately 35 and 43 times higher than the proposed background hemispheric values (10 and $2.8 \mu \mathrm{eq} / \mathrm{l})$ respectively at remote sites (Galloway et al., 1982; Casimiro et al., 1991). This may be due to secondary particles may be having the highest deposition fluxes. The mean ionic representation in winter RW samples suggests that $\mathrm{Ca}^{2+}$ contributed highest $(31 \%)$ followed by $\mathrm{SO}_{4}{ }^{2-}(28 \%)$ and $\mathrm{NH}_{4}{ }^{+}(14 \%)$, while $\mathrm{NO}_{3}^{-}(9 \%)$ ion makes a relatively moderate contribution compared with $\mathrm{Cl}^{-}(6 \%)$ and $\mathrm{Na}^{+}(\%)$ ions in RW. The high $\mathrm{Ca}^{2+}$ over Delhi may be attributed to the calcareous soil aerosolized into the atmosphere and washed out into the rain (Tiwari et al., 2016). High concentrations of $\mathrm{Ca}^{2+}$ are found in the precipitation collected in the initial stages of an event signifying rapid below-cloud scavenging of coarse calcium-containing particles (Chate et al., 2011). $\mathrm{Ca}^{2+}$ concentrations could also be linked to suspended road dust (Sanusi et al., 1996). The composition of precipitation over north India during the December to February reflects the marine origin of sea salt such as sodium and chloride as precipitation is due to the WD originating from the Caspian Sea and interacting with feeder moist airmass of Arabian Sea during the transit. The fraction of non-marine constituents could be due to the entrainment of atmospheric particulate matter in the precipitation en route the trajectories of air masses (Bisht et al., 2015). However, $\mathrm{NH}_{4}{ }^{+}$ion makes $14 \%$ of the total cations mass, which was the highest contribution after $\mathrm{Ca}^{2+}$. The concentration of $\mathrm{NH}_{4}{ }^{+}$over Delhi varied from 72.22 to $330.56 \mu \mathrm{eq} / 1$, with the mean of $172.91 \pm 83.32 \mu \mathrm{eq} / 1$. The high concentrations of $\mathrm{NH}_{4}{ }^{+}$might be due to agricultural activities and biomass burning (Khattak et al., 2012). The role of ammonium into the atmosphere works as a neutralizing agent of acids caused by $\mathrm{H}_{2} \mathrm{SO}_{4}$ and $\mathrm{HNO}_{3}$ in the RW and form as new salts like ammonium sulfate and nitrate (Bisht et al., 2015). The source of acidic species such as $\mathrm{SO}_{4}{ }^{2-}$ and $\mathrm{NO}_{3}{ }^{-}$ions may be either from local sources or long-range transport pollutants. The concentration of $\mathrm{NO}_{3}{ }^{-}(120.54 \pm 80.09 \mu \mathrm{eq} / \mathrm{l})$ in RW was also found higher at Delhi, which might be due to oxidation of $\mathrm{NO}_{\mathrm{x}}$ emitted from various sources such as combustion of fossil fuel, industrial activities, and biomass burning (Seinfeld and Pandis, 2006). Further, significant concentrations of $\mathrm{K}^{+}(13.84 \pm 8.35 \mu \mathrm{eq} / \mathrm{l})$ in the air mass confirmed the influence of biomass burning. In general, $\mathrm{K}^{+}$is considered as a tracer for biomass burning (Kulshrestha et al., 2004). The high concentrations of soiloriginated elements such as $\mathrm{Mg}^{2+}(50.33 \pm 33.04 \mu \mathrm{eq} / \mathrm{l})$ and $\mathrm{K}^{+} \quad(13.84 \pm 8.35 \mu \mathrm{eq} / \mathrm{l})$ in the RW during the study period were mainly due to high levels of total suspended particles/dusty soil, which are locally build up or transported from other places. Hence, these constituents 
Open access e-Journal

Earth Science India, eISSN: $0974-8350$

Vol. 9 (IV), October, 2016, pp. 150 - 166

http://www.earthscienceindia.info/

enter into RW by rainout and washout processes. The northern part of India is generally dusty and is a major contributor to total suspended particulate matter in the air (Tiwari et al., 2009).

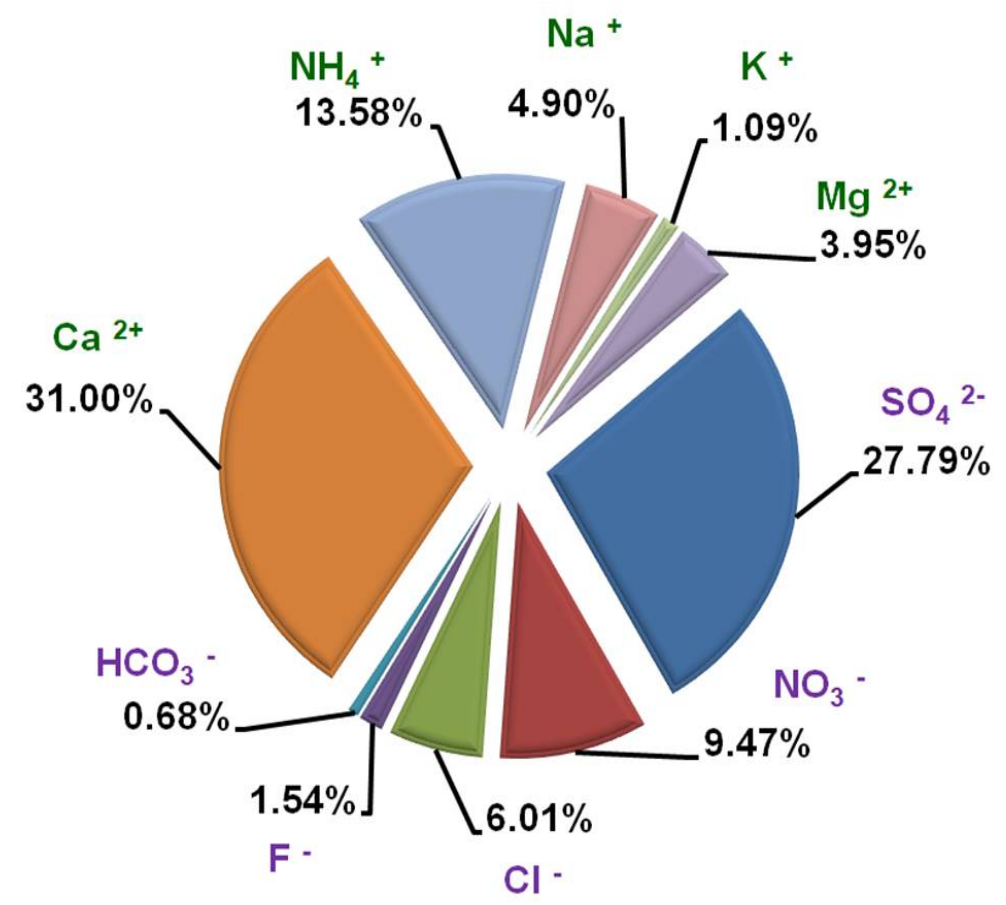

Fig. 4: Percentage contribution of total ionic composition in rainwater over Delhi during winter season.

Table-2: The volume weighted means (VWM) concentrations $(\mu \mathrm{eq} / \mathrm{l})$ of measured ionic species, $\mathrm{pH}$ and conductivity in winter rainwater over Delhi in 2014-15.

\begin{tabular}{|l|l|l|l|l|l|l|l|l|l|l|l|l|}
\hline & $\mathbf{F}$ & $\mathbf{C I}^{-}$ & $\mathbf{N O}_{3}{ }^{-}$ & $\mathbf{S O}_{4}{ }^{2-}$ & $\mathbf{N a}^{+}$ & $\mathbf{N H}_{4}{ }^{+}$ & $\mathbf{K}^{+}$ & $\mathbf{C a}^{2+}$ & $\mathbf{M g}^{2+}$ & $\mathbf{H C O}_{3}{ }^{-}$ & $\mathbf{p H}$ & $\mathbf{C o n d .}$ \\
\hline Mean & 19.59 & 76.59 & 120.54 & 353.88 & 62.40 & 172.91 & 13.84 & 394.72 & 50.33 & 8.62 & 5.76 & 94.22 \\
\hline SD & 13.74 & 57.19 & 80.09 & 214.91 & 59.18 & 83.32 & 8.35 & 193.52 & 33.04 & 6.55 & 0.61 & 50.71 \\
\hline & & & & & & & & & & & & \\
Max & 47.68 & 178.91 & 243.05 & 761.20 & 178.69 & 330.56 & 28.57 & 687.32 & 113.25 & 16.60 & 6.27 & 191.90 \\
\hline Min & 7.74 & 22.60 & 36.68 & 115.69 & 8.65 & 72.22 & 5.56 & 135.20 & 19.75 & 0.35 & 4.59 & 40.33 \\
\hline
\end{tabular}

\section{Marine Influence}

The influence of marine and non-marine source to the RW during the study period was assessed by calculating the equivalent ratio of measured ions using sodium as the reference element (Table-3). It is assumed that all sodium is of marine origin (Singh et al., 2007). Table-3 shows the calculated enrichment factors (EF) of $\mathrm{Cl}^{-}, \mathrm{Mg}^{2+}, \mathrm{K}^{+}, \mathrm{Ca}^{2+}$ and $\mathrm{SO}_{4}{ }^{2-}$ in reference to $\mathrm{Na}^{+}$using following equation $\mathrm{EF}=\left(\chi_{\mathrm{c}} / \mathrm{Na}^{+}\right)_{\text {Rain }} /\left(\chi_{\mathrm{c}} / \mathrm{Na}^{+}\right)_{\text {Sea, }}$, where $\chi_{c}$ is the concentration of desired ionic species ( $\mu$ eq/l) (Zhang et al., 2007; Bisht et al., 2015). The sea-salt fraction (SSF) and non-sea-salt fraction (NSSF) were also calculated as 100 * $[1 /(\mathrm{EF})]$ and $100-\mathrm{SSF}(\%)$ respectively. The analysis of EF reveals that all compounds are enriched with higher than unity, specifying considerable influences of other sources instead 
of marine sources. A fraction of non-marine constituents may be contributed to the entrainment of atmospheric particulate matter in the RW along the trajectory path of air masses (Norman et al., 2001). The high values of $\mathrm{EF}$ of $\mathrm{Ca}^{2+}, \mathrm{K}^{+}$and $\mathrm{SO}_{4}{ }^{2-}$ point towards their anthropogenic origin. The $\mathrm{EF}$ of $\mathrm{Mg}^{2+}$ indicates the marine source connectivity in $\mathrm{RW}$ samples (Zunckel et al., 2003; Migliavacca et al., 2004). The ratios of $\mathrm{Cl}^{-} / \mathrm{Na}^{+}(1.23), \mathrm{Mg}^{2+}$ $/ \mathrm{Na}^{+}(0.81), \mathrm{K}^{+} / \mathrm{Na}^{+}(0.22), \mathrm{Ca}^{2+} / \mathrm{Na}^{+}(6.33)$ and $\mathrm{SO}_{4}{ }^{2-} / \mathrm{Na}^{+}(5.67)$ were found to be higher than that of seawater (1.16), divulging that crustal (soil dust) and anthropogenic contribution of these ions are in the precipitation over Delhi. The predominant source of $\mathrm{Cl}^{-}$in the precipitation is sea spray. The compounds containing $\mathrm{Ca}^{2+}, \mathrm{Mg}^{2+}$ and $\mathrm{K}^{+}$are added to the atmosphere by soil erosion in the form of their carbonate salts (Ali et al., 2004). The NSSF of $\mathrm{Cl}^{-}, \mathrm{Ca}^{2+}, \mathrm{K}^{+}, \mathrm{Mg}^{2+}$, and $\mathrm{SO}_{4}{ }^{2}$ are 5.48, 99.31, 90.17, 71.86 and $97.80 \%$, respectively, substantiating the dominance of crustal or anthropogenic sources of $\mathrm{Ca}^{2+}, \mathrm{K}^{+}, \mathrm{Mg}^{2+}$ and $\mathrm{SO}_{4}^{2}$. Various studies have sighted similar results (Rastogi and Sarin, 2005; Gobre et al., 2010; Kumar et al., 2014, Bisht et al., 2015). The major source of calcium in Indian precipitation is soil dust particles emitted from the earth's surface (Kulshrestha et al., 2003; Tiwari et al., 2009).

Table-3: Equivalent concentration ratios of ionic components with respect to sodium.

\begin{tabular}{|c|c|c|c|c|c|}
\hline & $\mathbf{C l}^{-} / \mathbf{N a}^{+}$ & $\mathbf{M g}^{2+} / \mathbf{N a}^{+}$ & $\mathbf{K}^{+} / \mathbf{N a}^{+}$ & $\mathbf{C a}^{2+} / \mathbf{N a}^{+}$ & $\mathbf{S O}_{4}{ }^{2-} / \mathbf{N a}^{+}$ \\
\hline Rainwater & 1.23 & 0.81 & 0.22 & 6.33 & 5.67 \\
\hline Seawater * & 1.16 & 0.227 & 0.0218 & 0.0439 & 0.125 \\
\hline $\mathbf{E F}$ & 1.06 & 3.55 & 10.17 & 144.08 & 45.37 \\
\hline $\mathbf{S S F}(\%)$ & 94.52 & 28.14 & 9.83 & 0.69 & 2.20 \\
\hline $\mathbf{N S S F}(\%)$ & 5.48 & 71.86 & 90.17 & 99.31 & 97.80 \\
\hline
\end{tabular}

Keene et al. (1986)

\section{Contributions of Sulfuric and Nitric Acid to Total Acidity in the Rainwater}

To understand the relative contributions of sulfuric and nitric acid to the total acidity in RW (Chate and Devara, 2009), the ratios between $\mathrm{SO}_{4}{ }^{2-}$ and $\mathrm{NO}_{3}{ }^{-}$were estimated and compared with studies undertaken in India and abroad (Table-4). The ratio between $\mathrm{SO}_{4}{ }^{2-}$ and $\mathrm{NO}_{3}{ }^{-}$was found to be $2.94 \pm 2.64$, suggesting that the contribution to the acidity in $\mathrm{RW}$ was about $75 \%$ due to sulfuric acid and $25 \%$ from nitric acid. The high influence of sulfur was due to urban industrial activities and vehicular emission. Bisht et al. (2015) reported that a low concentration of $\mathrm{NO}_{3}{ }^{-}$due very small inputs of nitrogenous fertilizers in the region caused by low crop density in the prolonged period of dry weather. The observed ratio was quite similar to various parts of India (Gobre et al., 2010; Tiwari et al., 2012; Kumar et al., 2014; Bisht et al., 2015; Tiwari et al., 2016; Kumar et al., 2016); however, higher ratios were found overseas in Singapore, Beijing (China), Guaiba (Brazil), Erzurum (Turkey), and Guangzhou (China) (Flues et al., 2002; Yang et al., 2004; Migliavacca et al., 2005; Bayraktar and Turalioglu, 2005; Cao et al., 2009). The relative contributions of the ions to the acidity of RW were variable for the event to event and location to location. Earlier studies reported the contributions of $\mathrm{H}_{2} \mathrm{SO}_{4}$ and $\mathrm{HNO}_{3}$ in $\mathrm{RW}$ were between $60-70 \%$ and $30-40 \%$, respectively (Al-Khashman, 2005; Tiwari et al., 2012; Bisht et al., 2015; Tiwari et al., 2016). The ratios $\mathrm{NH}_{4}{ }^{+} / \mathrm{NO}_{3}{ }^{-}$and $\mathrm{NH}_{4}{ }^{+} / \mathrm{SO}_{4}{ }^{2-}$ were 1.43 and 0.48 respectively. 
Table-4: Comparison ratio of $\mathrm{SO}_{4}{ }^{2-} / \mathrm{NO}_{3}{ }^{-}$at various locations in India and abroad.

\begin{tabular}{|l|c|l|}
\hline \multicolumn{1}{|c|}{ Location } & SO $_{4}{ }^{2-} / \mathbf{N O}_{\mathbf{3}}{ }^{-}$ & \multicolumn{1}{c|}{ References } \\
\hline NCR of Delhi, India & 2.94 & Present Study \\
\hline Indo- Gangetic Plains, India & 1.79 & Tiwari et al., 2016 \\
\hline Gulmarg, J \& K State, India & 1.45 & Kumar et al., 2016 \\
\hline Varanasi, India & 2.2 & Bisht et al., 2015 \\
\hline New Delhi (Winter season) & 2.21 & Kumar et al., 2014 \\
\hline Kullu, India & 1.47 & Tiwari et al., 2012 \\
\hline Goa, India & 1.92 & Gobre et al., 2010 \\
\hline Guangzhou, China & 3.06 & Cao et al., 2009 \\
\hline Erzurum, Turkey & 11.6 & Bayraktar and Turalioglu, 2005 \\
\hline Guaiba, Brazil & 8.7 & Migliavacca et al., 2005 \\
\hline Beijing, China & 2.96 & Yang et al., 2004 \\
\hline Singapore & 3.5 & Flues et al., 2002 \\
\hline
\end{tabular}

\section{Acidification and Neutralization Potentials}

Sulphuric $\left(\mathrm{H}_{2} \mathrm{SO}_{4}\right)$, nitric $\left(\mathrm{HNO}_{3}\right)$, and some organic acids are the main contributors to the wet precipitation acidification process (Migliavacca et al., 2005; Zhao et al., 2013). Relative contribution of $\mathrm{SO}_{4}{ }^{2-}$ and $\mathrm{NO}_{3}{ }^{-}$toward acidification were computed using the ratio $\left[\mathrm{SO}_{4}{ }^{2-} /\left(\mathrm{SO}_{4}{ }^{2-}+\mathrm{NO}_{3}{ }^{-}\right)\right]$and $\left[\mathrm{NO}_{3}{ }^{-} /\left(\mathrm{SO}_{4}{ }^{2-}+\mathrm{NO}_{3}{ }^{-}\right)\right]$respectively. $\mathrm{H}_{2} \mathrm{SO}_{4}$ and $\mathrm{HNO}_{3}$ contributed 75 and $25 \%$ respectively, to the acidity in winter RW over Delhi, signifying that sulfurrelated emissions are a major causal factor for acidity compared with nitrogen oxides. Similar observations have been made in Delhi (Kumar et al., 2014) and over coastal India cities (Das et al., 2010). The source of $\mathrm{SO}_{4}{ }^{2-}$ may be traced back to thermal power plant emissions and crustal sources (Migliavacca et al., 2005; Fang et al., 2013).

The neutralization factors (NF) are calculated for $\mathrm{NH}_{4}{ }^{+}, \mathrm{Ca}^{2+}$ and $\mathrm{Mg}^{2+}$ using formula: $\mathrm{NF}_{\mathrm{X}}=\left[\mathrm{X} / \mathrm{SO}_{4}{ }^{2-}+\mathrm{NO}_{3}{ }^{-}\right]$where $\mathrm{X}$ is the cation for which $\mathrm{NF}$ is calculated. The winter season average NFs of cations follow the order $\mathrm{Ca}^{2+}(0.83)>\mathrm{NH}_{4}^{+}(0.36)>>\mathrm{Mg}^{+}(0.11)$ over Delhi. In this study, $\mathrm{Ca}^{2+}$ was the more important neutralization substance than $\mathrm{NH}_{4}{ }^{+}$. In another study, Kumar et al. (2014) also found similar pattern over Delhi in the winter season of year 2010-11 with order of NFs: $\mathrm{NH}_{4}^{+}(0.82)>\mathrm{Ca}^{2+}(0.79)>\mathrm{Mg}^{+}(0.07)$, however, Ali et al . (2004) reported $\mathrm{Ca}^{2+}$ as major neutralizing species in RW samples of the winter season collected during 2001-2003 over Delhi. The higher contribution of $\mathrm{NH}_{4}{ }^{+}$the second largest cation in RW over Delhi may be attributed to the ever increasing vehicular density and to the initiation of catalytic converters in public transport. The catalytic convertor-fitted vehicles causing $\mathrm{NH}_{4}{ }^{+}$emissions have been described in previous studies across other parts of the country (Kumar et al., 2014; and references therein). A strong connection between $\mathrm{NH}_{3}$ and $\mathrm{CO}$ emissions and vehicle density has been found in an urban area of Rome (Perrino et al., 2002). For the present study, the implementation of catalytic converters and clean fuel for transport fleet in Delhi may have reduced CO and NO emissions along with a significant positive contribution to $\mathrm{NH}_{3}$ emissions. 


\section{Trajectory Analysis for source Analysis}

To investigate the origins of pollutants in RW over Delhi, 72-h air mass backward trajectories were computed for each rain event using the Hybrid Single Particle Lagrangian Integrated Trajectory (HYSPLIT) model of the National Oceanic and Atmospheric Administration (NOAA), USA (Draxler and Rolph, 2003). The back-trajectories model was run for $500 \mathrm{~m}$ altitude for representing the boundary layer. Based on the backward trajectories and re-analysis of meteorological data, the air masses in the rainy days in the present study may be broadly divided into three different clusters (Fig. 5). Air masses in 'Cluster 1' (easterly wind regime) contributed $65.3 \%$ of the total rainfall during the winter season observations. This cluster of air masses originated from Himalayan range, traveled through a populated region of Uttar Pradesh accounted for $43.9 \%$ of $\sum$ ions during sampling periods. Air masses in 'Cluster 2' (westerly wind regime), accounting for $6 \%$ of the rainfall, were transferred from Thar desert of central Pakistan and Rajasthan. Air masses in 'Cluster 2' accounted for $29.3 \%$ of Eions during sampling periods. This cluster of air masses, characterized by high loadings of ionic species, was significantly polluted due to low rainfall amount and heavy sand and dust emissions along the passing areas in wintertime. Tiwari et al., (2014) found that back-trajectories coming from Thar Desert region are one of the major sources of enhanced PM mass concentrations over Delhi. Air masses in 'Cluster 3' (southerly/southeasterly wind regime) contributing $28.7 \%$ of the total sampled rainfall, was primarily from the region of central India. Air masses in 'Cluster 3' accounted for $26.8 \%$ of Eions. Guttikunda et al., (2014) highlighted that the particulate matter pollution in Central India is highest due to the density of the power plants in the region and high installed generation capacity. The majority of acidic rain events were of 'Cluster 3' airmass followed by 'Cluster 1'; however, the rains were alkaline when the winds were 'Cluster 2' type. It may be noted that the trajectory information has certain inherent restrictions due to the chances of resources originated from one location being mixed with others.

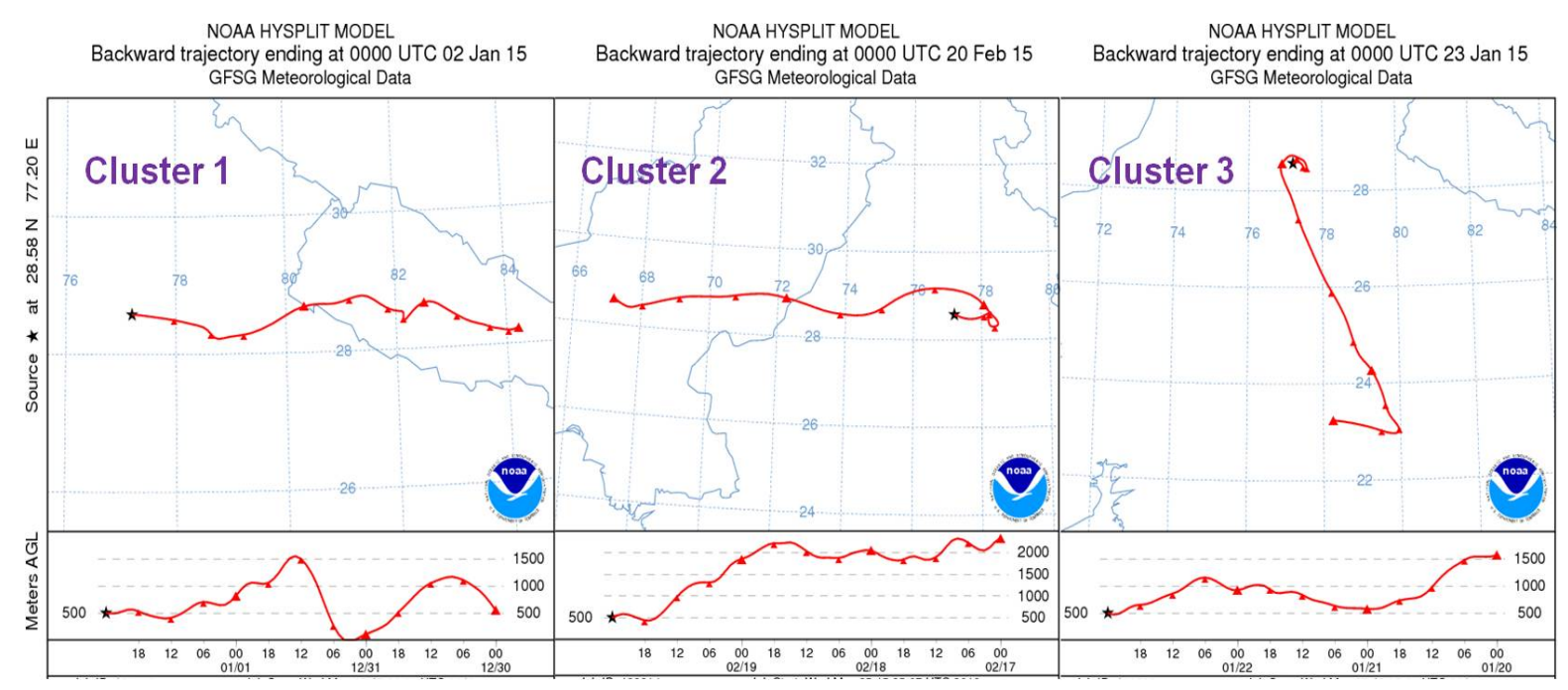

Fig. 5: Representative wind directions drawn by HYSPLIT Trajectory Model.

\section{Principal Component Analysis}

Principal components analysis (PCA) was performed on the RW data set comprised of major ions to identify and associate their possible sources. The software used for PCA 
analysis was SPSS 16.0 for Windows. All data used for PCA analysis were the first autoscaled, as they had the same importance for sample discrimination (Cerqueira et al., 2014). Factors with an eigenvalue $>1$ were retained. PCA yielded in total three significant factors, explaining about $95.6 \%$ of the total data variance. Loadings of the varimax rotated factors are presented in Table-5. The first factor (Factor 1) explains $73.5 \%$ of the total variance, characterized by a high loading of the most ions $\left(\mathrm{F}^{-}, \mathrm{Cl}^{-}, \mathrm{NO}_{3}{ }^{-}, \mathrm{SO}_{4}{ }^{2-}, \mathrm{Na}^{+}, \mathrm{K}^{+}, \mathrm{Ca}^{2+}\right.$ and $\mathrm{Mg}^{2+}$ ) except ammonium and bicarbonate. It indicates a well-mixed source influenced by crustal, anthropogenic as well as marine origins, possibly localized as well as transported over a long distance. The second factor (Factor 2) is shown by a high loading of $\mathrm{NH}_{4}^{+}$ accounting for $11.4 \%$ of the total variance and engaging a local biomass burning and agricultural activities because of low wind speed and temperature along with lower boundary layer heights. The third factor (Factor 3) is highly loaded by $\mathrm{HCO}_{3}{ }^{-}$with a variation of $10.7 \%$. The higher $\mathrm{HCO}_{3}{ }^{-}$loading at this factor can be associated to $\mathrm{Ca}^{2+}$ and $\mathrm{Mg}^{2+}$ neutralization process of rain acids, by suspended $\mathrm{CaCO}_{3}$ and $\mathrm{MgCO}_{3}$ in air, originated mostly from soil dust (Shrestha et al., 2013; Cerqueira et al., 2014).

Table-5: Factor analysis on the chemical species of rainwater.

\begin{tabular}{|c|c|c|c|}
\hline Variable & Factor 1 & Factor 2 & Factor 3 \\
\hline $\mathbf{F}^{-}$ & 0.899* & 0.095 & 0.318 \\
\hline $\mathrm{Cl}^{-}$ & $0.973 *$ & -0.069 & -0.187 \\
\hline $\mathrm{NO}_{3}{ }^{-}$ & $0.925 *$ & -0.138 & -0.233 \\
\hline $\mathrm{SO}_{4}{ }^{2-}$ & $0.951 *$ & 0.185 & 0.108 \\
\hline $\mathrm{HCO}_{3}{ }^{-}$ & 0.329 & -0.188 & $0.904 *$ \\
\hline $\mathrm{Na}^{+}$ & $0.972 *$ & -0.116 & -0.041 \\
\hline $\mathbf{N H}_{4}{ }^{+}$ & 0.156 & $0.976 *$ & 0.027 \\
\hline $\mathbf{K}^{+}$ & $0.954^{*}$ & -0.201 & -0.202 \\
\hline $\mathrm{Ca}^{2+}$ & 0.938* & 0.178 & 0.01 \\
\hline $\mathrm{Mg}^{2+}$ & $0.985^{*}$ & -0.02 & -0.07 \\
\hline Eigen values & 7.356 & 1.14 & 1.068 \\
\hline Variance $\%$ & 73.56 & 11.40 & 10.68 \\
\hline Cumulative \% & 73.56 & 84.96 & 95.64 \\
\hline Probable Origin & Mixed Sources & $\begin{array}{l}\text { Biomass } \\
\text { burning }\end{array}$ & Roadside dust \\
\hline
\end{tabular}

*Bold data indicate that the loading for the variables is higher than 0.50 .

\section{Conclusions}

Chemical characteristics of precipitation were investigated during the winter season of 2014-15 at an urban site in Delhi. The weighted mean $\mathrm{pH}$ and specific conductivity of RW were $5.76 \pm 0.61$ and $31.6 \pm 31.0 \mu \mathrm{S} / \mathrm{cm}$, respectively with $\sim 42 \%$ samples being acidic (mean $\mathrm{pH}=5.20$ ). The contribution of $\mathrm{SO}_{4}{ }^{2-}$ and $\mathrm{NO}_{3}{ }^{-}$to the acidic rain samples were $74 \%$ 
and $26 \%$ respectively. The specific conductively was found to be having $\sim 16 \%(84.93$ $\mu \mathrm{S} / \mathrm{cm}$ ) lower specific conductivity for the acid RW samples as compared to the non-acidic RW samples $(101.20 \mu \mathrm{S} / \mathrm{cm})$. The sum of the measured VWM of ionic constituents was $1273.41 \pm 749.91 \mu \mathrm{eq} / 1$, with the contribution of anions in the sum of the measured ion being $17 \%$ lower than the measured sum of cations. The mean values of $\mathrm{SO}_{4}{ }^{2-}(353.9 \mu \mathrm{eq} / \mathrm{l})$ and of $\mathrm{NO}_{3}{ }^{-}(120 \mu \mathrm{eq} / \mathrm{l})$ were approximately 35 and 43 times higher than the proposed background hemispheric values $(10$ and $2.8 \mu \mathrm{eq} / 1)$ respectively at remote sites. $\mathrm{NH}_{4}{ }^{+}$ion makes $14 \%$ of the total cation mass, which was the highest contribution after $\mathrm{Ca}^{2+}$. The high concentrations of $\mathrm{NH}_{4}^{+}$might be due to agricultural activities and biomass burning. Equivalent ratio (EF) method was used to identify the influence of marine and non-marine source to the RW. The ratios of $\mathrm{Cl}^{-} / \mathrm{Na}^{+}(1.23), \mathrm{Mg}^{2+} / \mathrm{Na}^{+}(0.81), \mathrm{K}^{+} / \mathrm{Na}^{+}(0.22), \mathrm{Ca}^{2+} / \mathrm{Na}^{+}(6.33)$ and $\mathrm{SO}_{4}{ }^{2-} / \mathrm{Na}^{+}(5.67)$ were found to be higher than that of seawater, divulging that crustal (soil dust) and anthropogenic contribution of these ions are in the precipitation over Delhi. Neutralization factors of cations follow in the order of $\mathrm{Ca}^{2+}(0.83)>\mathrm{NH}_{4}^{+}(0.36)>>\mathrm{Mg}^{2+}(0.11)$ over Delhi. Second higher contribution of $\mathrm{NH}_{4}^{+}$in $\mathrm{RW}$ over Delhi may be attributed to the ever increasing vehicular density and the initiation of catalytic converters in public transport. Back-trajectory analysis $(72 \mathrm{~h})$ indicated that the air masses over Delhi can be divided into three clusters, prevailing from easterly, westerly and southerly/southeasterly wind regime respectively. PCA was performed, grouping the major analyzed cations and anions into three different factors and were assigned to mixed source influenced by crustal, anthropogenic and marine origins whereas $\mathrm{NH}_{4}{ }^{+}$to local biomass burning and $\mathrm{HCO}_{3}{ }^{-}$to soil dust.

Acknowledgements: The authors gratefully thank the Vice Chancellor, Gautam Buddha University for the encouragement and support during the study period. Authors are also thankful to Director General, Indian Meteorological Department (IMD); Assistant Chief of Air Staff (Meteorology), Indian Air Force; Director, Indian Institute of Tropical Meteorology (IITM) and Director, Bose Institute. The authors sincerely thank the scientist from various Institutions for their suggestions and comments, which have helped in improving the manuscript. The authors gratefully acknowledge the NOAA Air Resources Laboratory (ARL) for the provision of the HYSPLIT transport and dispersion model and/or READY website (http://www.ready.noaa.gov) used in this publication.

\section{References}

Ali, K., Momin, G.A., Tiwari, S., Safai, P.D., Chate, D.M., and Rao, P.S.P. (2004) Fog and Precipitation Chemistry at Delhi, North India. Atmos. Environ., v. 38, pp. 4215-4222.

Al-Khashman, O.A. (2005) Study of chemical composition in wet atmospheric precipitation in Eshidiya area, Jordan. Atmos Environ., v. 39, pp.6175-6183.

Al-Khashman, O.A. (2009) Chemical characteristics of rainwater collected at a western site of Jordan. Atmos. Res., v.91, pp. 53-61.

Al-Momani, I.F., Ataman, O.Y., Anwari, M.A., Tuncel, S., Köse, C. and Tuncel, G. (1995) Chemical Composition of precipitation near an industrial area at Izmir, Turkey. Atmos. Environ., v. 29, pp. 11311143.

Aneja, V. P., Wang, B., Tong D.Q., Kimball, H. and Steger, J. (2006) Characterization of major chemical components of fine particulate matter in North Carolina. J. Air \& Waste Management Association, v. 56, pp.1099-1107.

Akpo, A.B. Galy-Lacaux, C., Laouali, D., Delon, C., Liousse, C., Adon, M., Gardrat, E., Mariscal, A. and Darakpa, C. (2015) Precipitation chemistry and wet deposition in a remote wet savanna site in West Africa: Djougou (Benin). Atmos. Environ., v.115, pp.110-123.

Baron, J. and Denning, A.S. (1993) The Influence of mountain meteorology on precipitation chemistry at low and high elevations of the Colorado Front Range, USA. Atmos. Environ., v. 27, pp. 2337-2349.

Bayraktar, H. and Turalioglu, F.S. (2005) Composition of wet and bulk deposition in Erzurum, Turkey. Chemosphere, v. 59, pp.1537-1546. 
Open access e-Journal

Earth Science India, eISSN: $0974-8350$

Vol. 9 (IV), October, 2016, pp. 150 - 166

http://www.earthscienceindia.info/

Bisht, D.S., Tiwari, S., Srivastava, A.K., Singh, J.V., Singh, B.P. and Srivastava, M.K. (2015) High concentration of acidic species in rainwater at Varanasi in the Indo- Gangetic Plains, India. Nat. Hazards, v. 75, pp. 2985-3003.

Budhavant, K.B., Rao, P.S.P., Safai, P.D. and Ali, K. (2011) Influence of local sources on rainwater chemistry over Pune region, India. Atmos. Res., v. 100, pp.121-131.

Calvo, A.I., Olmo, F.J., Lyaman i, H., Alados-Arboledas, L., Castro, A., Fernandez-Raga, M. and Fraile, R. (2010) Chemical composition of wet precipitation at the background EMEP station in Víznar (Granada, Spain) (2002-2006). Atmos. Res., v. 96, pp. 408-420.

Cao, Yu-Z., Wang, S., Zhang, G., Luo, J., Lu, S. (2009) Chemical characteristics of wet precipitation at an urbansite of Guangzhou, South China. Atmos Res., v. 94, pp.462-469.

Casimiro, A.P., Salgueiro, M.L. and Nunes, V.T. (1991) Seasonal and Air-Mass Trajectory Effects on rainwater quality at the South-Western European Border. Atmos. Environ., v. 25, pp. 2259-2266.

Cerqueira, M.R.F., Pinto, M.F., Derossi,I.N., Esteves, W.T., Santos, M.D.R., Matos, M.A.C., Lowinsohn, D., Matos, R.C.(2014) Chemical characteristics of rainwater at a southeastern site of Brazil. Atmospheric Pollution Research, v. 5, pp. 253,261.

Chand, R. and Singh, C. (2015) Movements of western disturbance and associated cloud convection. J. Ind. Geophys. Union, v.19, no.1, pp. 62-70.

Charlson, R.J. and Rodhe, H. (1982) Factors controlling the acidity of natural rainwater. Nature, v. 295, pp. 683-885.

Chate, D.M. and Devara, P.C.S. (2009) Acidity of raindrop by uptake of gases and aerosol pollutants. Atmos. Environ., v. 43, pp.1571-1577.

Chate, D.M., Murugavel, P., Ali, K., Tiwari, S. and Beig, G. (2011) Below-thunderstorm rain scavenging of atmospheric aerosols for aerosol deposition models. Atmos. Res., v. 99, pp. 528-536.

Das, R., Granat, L., Leck, C., Praveen, P.S. and Rodhe, H. (2011) Chemical composition of rainwater at Maldives Climate Observatory at Hanimaadhoo (MCOH). Atmos. Chem. Phys., v. 11, pp. 3743-3755.

Draxler R.R. and Rolph G.D. (2003) HYSPLIT (HYbrid Single-Particle Lagrangian Integrated Trajectory) Model access via NOAA ARL READY Website (http://www.arl.noaa.gov/ready/ hysplit4. html). NOAA Air Resources Laboratory, Silver Spring, MD.

Fang, Y., Wang, X., Zhu, F., Wu, Z., Li, J., Zhong, L., Chen, D. and Yoh, M. (2013) Three decade change in chemical change of precipitation in Guangzhou city, southern China: has precipitation recovered from acidification following sulphur dioxide emission control? Tellus, v. B65, pp. 20213. doi:10.3402/tellusb.v65i0.20213

Flues, M., Hamma, P., Lames, M.J.L., Dantas, E.S.K. and Fornaro, A. (2002) Evaluation of the rainwater acidity of a rural region due to a coal-fired power plant in Brazil. Atmos. Environ., v. 36, pp.2397-2404.

Galloway, J.N., Likens, G.E., Keene, W.C. and Miller, J.M. (1982) The Composition of precipitation in remote areas of the world. J. Geophys. Res., v. 87, pp. 8771-8776.

Galloway, J.N., Likens, G.E. and Hawley, M.E. (1984) Acid precipitation: natural versus anthropogenic components. Science, v. 226, pp. 829-831.

Ganguly, D., Jayaraman , A., Rajesh ,T.A. and Gadhavi, H. (2006) Wintertime aerosol properties during foggy and non foggy days over urban center Delhi and their implications for shortwave radioative forcing. J. Geophysical Research, v. 111, pp. D15217, doi: 10.1029/2005JD007029.

Gillett, R. and Ayers, G. (1991) The use of thymol as a biocide in rainwater samples. Atmospheric Environment v. 25A, pp. 2677-2681.

Gobre, T., Salve, P.R., Krupadam, R.J., Bansiwal, A., Shastry, S. and Wate, S.R. (2010) Chemical composition of precipitation in the coastal environment of India. Bull. Environ Contam. Toxicol., v. 85, pp.48-53.

Guttikunda, S.K., Jawahar, P. (2014) Atmospheric emissions and pollution from the coal-fired thermal power plants in India. Atmospheric Environment, v. 92, pp. 449 - 460.

Indian Meteorological Department (IMD), (2016) Website: www.imd.gov.in. Accessed on 06 May 2016.

IPCC (2001) Climate Change, 2001, The Scientific basis, contribution of working group I to the third assessment report of the Intergovernmental Panel on Climate Change (IPCC). Cambridge University Press, Cambridge, U.K.

IPCC (2007) Climate Change, The Physical Science Basis, Cambridge University Press, Cambridge.

Khattak, M.I., Rehana, K. and Jana, A. (2012) Chemical precipitation of aerosols particulates of rain waters reference to atmospheric pollution at Lahore/Pakistan. Sci. Int. (Lahore), v. 24, pp. 81-86. 
Kulshrestha, U.C., Kulshrestha, M. J., Sekar, R., Sastry, G.S.R. and Vairamani, M. (2003) Chemical characteristics of rainwater at an urban site of south Central India. Atmos. Environ., v. 37, pp. 30193026.

Kulshrestha, U.C., Azhaguvel, S.N., Rao, T. and Sekar, R. (2004) Relationship of sulphate aerosols with natural and anthropogenic sources in South-central India. Proceedings of $8^{\text {th }}$ IGAC Conference, September 4-9, 2004, Christchurch, New Zealand.

Kulshrestha, U.C., Granat, L., Engardt, M. and Rodhe, H. (2005) Review of precipitation chemistry studies in India- A search for regional patterns. Atmos. Environ., v. 39, pp. 7403-7419.

Kumar, B., Singh, S., Gupta, G.P., Lone, F. A. and Kulshrestha, U.C. (2016) Long range transport and wet deposition fluxes of major chemical species in snow at Gulmarg in North Western Himalayas (India). Aerosol and Air Quality Research, v. 16, pp. 606-617.

Kumar, N. and Yadav, B.P. (2015) Winter frequency of western disturbances and precipitation indices over Himachal Pradesh, India: 1977-2007. Atmósfera, v. 28(1), pp. 63-70.

Kumar, P., Yadav, S., Kumar, A.(2014) Sources and processes governing rainwater chemistry in New Delhi, India. Nat Hazards, 74:2147-2162.

Kuniyal, J.C., Sharma, M., Chand, K. and Mathela, C.S. (2015) Water soluble ionic components in particulate matter $\left(\mathrm{PM}_{10}\right)$ during high pollution episode days at Mohal and Kothi in the North-Western Himalaya, India. Aerosol and Air Quality Research, v. 15, pp. 529-543.

Lange, C.A., Matschullat, J., Zimmermann, F., Sterzik, G. and Wienhaus, O. (2003) Fog frequency and chemical composition of fog water- a relevant contribution to atmospheric deposition in the eastern Erzgebirge, Germany. Atmospheric Environment, v. 37, pp. 3731-37 39.

Li, C. L., Kang, S.C., Zhang, Q.G. and Kaspari, S. (2007) Major ionic composition of precipitation in the Nam Co Region, Central Tibetan Plateau. Atmos. Res. v. 85, pp. 351- 360.

Maji, S., Ahmed, S. and Siddiqui,W.A.(2015) Air quality assessment and its relation to potential health impacts in Delhi, India. Current Science, v. 109 (5), pp. 902.

Menon, S., Hansen, J., Nazarenko, L. and Luo, Y. (2002) Climate effects of elemental carbon aerosols in China and India. Science, v. 297, pp. 2250- 2253.

Migliavacca, D., Teixeira, E. C., Pires, M. and Fachel, J. (2004) Study of chemical elements in atmospheric precipitation in South Brazil. Atmos. Environ., v. 3, pp. 1641-1656.

Migliavacca, D., Teixeira, E.C., Wiegand, F., Machado, A. and Sanchez, J. (2005) Atmospheric precipitation and chemical composition of an Urban Site, Guaiba Hydrographic Basin, Brazil. Atmos. Environ., v. 39, pp.1829- 1844 .

Norman, M., Das, A.N., Pillai, A.G., Granat, L. and Rodhe, H. (2001) Influence of air mass trajectories on the chemical composition of precipitation in India. Atmos. Environ., v. 35, pp. 4223-423.

Peña, R.M., Garcı'a, S., Herrero, C., Losada, M., Va'zquez, A. and Lucas, T. (2002) Organic acids and aldehydes in rainwater in a northwest region of Spain. Atmos. Environ., v. 36(34), pp. 5277-5288.

Perrino, C., Catrambone, M., Bucchianico, A.D.M.D. and Allegrini, I. (2002) Gaseous ammonia in the urban area of Rome, Italy and its relationship with traffic emissions. Atmos. Environ., v. 36, pp. 5385-5394.

Piñeiro, J.M., Rodríguez, E.L., Pérez C.M., Heras G.B., Carou, I.T., Mahía P.L., Lorenzo S.M. and Rodríguez D.P. (2014) Influence of marine, terrestrial and anthropogenic sources on ionic and metallic composition of rainwater at a Suburban Site (Northwest Coast of Spain). Atmos. Environ., v. 88, pp. 30-38.

Rastogi, N. and Sarin, M.M. (2005) Chemical characteristics of individual rain events from a semi-arid region in India: three-year study. Atmos Environ., v. 39, pp. 3313-3323.

Safai, P.D., Budhvant, P.S.P., Ali, K. and Sinha, A. (2010) Source characterization for aerosols constituents and changing roles of calcium and ammonium aerosols in the neutralization of aerosol acidity at a Semiurban Site in SW India. Atmos. Res. v. 98, pp. 78-88.

Salve, P.R., Gobre, T., Lohkare, H., Krupadam, R.J., Bansiwal, A., Ramteke, D.S. and Wate, S.R. (2011) Source identification and variation in the chemical composition of rainwater at coastal and industrial areas of India. J. Atmos. Chem., v. 68, pp. 183-198.

Sanusi, A., Wortham, H., Millet, M. and Mirabel, P. (1996) Chemical composition of rain water in Eastern France. Atmos. Environ., v. 30, pp.59-71.

Seinfeld, J.H. and Pandis, S.N. (2006) Atmospheric chemistry and physics- from air pollution to climate change (2nd Edition), John Wiley \& Sons.

Shrestha, S., Pandey,V. P.,Yoneyama,Y., Shrestha,S. and Kazama,F., (2013) An evaluation of rainwater quality in Kathmandu Valley, Nepal. Sustainable Environment Research, v. 23, pp. 341-350.

Singh, K.P., Singh, V.K., Malik, A., Sharma, N., Murthy, R.C. and Kumar, R. (2007) Hydrochemistry of wet atmospheric precipitation over an urban area in Northern Indo-Gangetic Plains. Environ Monit. Assess., v.131, pp. 237-254. 
Open access e-Journal

Earth Science India, eISSN: $0974-8350$

Vol. 9 (IV), October, 2016, pp. 150 - 166

http://www.earthscienceindia.info/

Singh, S. and Kulshrestha, U. C. (2012) Abundance and distribution of gaseous ammonia and particulate ammonium at Delhi, India. Biogeosciences, v. 9, pp. 5023-5029.

Tiwari, S., Hopke, P.K., Thimmaiah, D., Dumka, U.C., Srivastava, A.K, Bisht, D.S., Rao, P.S.R., Chate, D.M., Srivastava, M.K. and Tripathi, S.N. (2016) Nature and Sources of Ionic Species in Precipitation across the Indo-Gangetic Plains, India. Aerosol and Air Quality Research, v. 16, pp. 943-957.

Tiwari, S., Bisht, D.S., Srivastava, A.K., Pipal, A.S., Taneja A., Srivastava, M.K. and Attri, S.D. (2014) Variability in atmospheric particulates and meteorological effects on their mass concentrations over Delhi, India. Atmospheric Research, v. 145-146, pp. 45-56.

Tiwari, S., Chate, D.M., Bisht, D.S., Srivastava, M.K. and Padmanabhamurty, B. (2012) Rainwater chemistry in the North Western Himalayan Region, India. Atmos. Res. v. 104-105, pp.128-138.

Tiwari, S., Srivastava, A.K., Bisht, D.S., Bano, T., Singh, S., Behura, S., Srivastava, M.K., Chate, D.M., Padmanabhamurty, B. (2009) Black carbon and chemical characteristics of PM10 and PM2.5 at an urban site of North India. J. Atmos. Chem. v. 6, pp. 193-209.

Tiwari, S., Bisht, D.S. and Srivastava, A.K., (2008) Chemical Characteristics of Water Soluble Components of Fine Particulate Matter, PM2.5, at Delhi, India. e-Journal Earth Science India, v. I (III), pp. 72-86. http://www.earthscienceindia.info/

Tiwari, S., Kulshrestha, U.C. and Padmanabhamurty, B. (2007) Monsoon rain chemistry and source apportionment using receptor modeling in and around National Capital Region (NCR) of Delhi, India. Atmos. Environ., v. 41, pp. 5595-5604.

Tyagi, S., Tiwari, S., Mishra, A., Hopke, P.K., Attri, S.D., Srivastava, A.K. and Bisht, D.S. (2016) Spatial variability of concentrations of gaseous pollutants across the National Capital Region of Delhi, India, Atmospheric Pollution Research, http://dx.doi.org/10.1016/j.apr.2016.04.008

Wang, H. and Han, G. (2011) Chemical composition of rainwater and anthropogenic influences in Chengdu, Southwest China. Atmos. Res., v. 99(2), pp. 190-196.

Yang, F., He, K., Lei, Y., Ma, Y., Yu, X., Tanaka, S., Okuda, K. and Iwase, T. (2004) Chemical characters of atmospheric precipitation in Beijing in years of 2001-2003, (in Chinese with English abstract), China. Environ. Sci . v. 4, pp. 538-541.

Zhang, M., Wang, S., Wu, F., Yuan, X. and Zhang, Y. (2007) Chemical composition of wet precipitation and anthropogenic influence at a developing urban site in Southeastern China. Atmos. Res., v. 84, pp. 311322.

Zhao, M., Li, L., Liu, Z., Chen, B., Huang, J., Cai, J. and Deng, S. (2013) Chemical composition and sources of rainwater collected at a Semi-rural site in Ya'an, Southwestern China. Atmospheric and Climate Sciences, v. 3, pp. 486 - 496.

Zhao, Z., Tian, L., Fischer, E., Li, Z. and Jiao, K. (2008) Study of chemical composition of precipitation at an Alpine site and a rural site in the Urumqi River Valley, Eastern Tien Shan, China. Atmos. Environ. v. 42, pp. 8934-8942.

Zunckel, M., Saizar, C. and Zarauz, J. (2003) Rainwater composition in northeast Uruguay. Atmos. Environ. v. 37, pp. 1601-1611.

(Received: 18.06.2016; Accepted: 28.10.2016) 